\title{
The impact of model resolution on the simulated Holocene retreat of the southwestern Greenland ice sheet using the Ice Sheet System Model (ISSM)
}

\author{
Joshua K. Cuzzone ${ }^{1,2}$, Nicole-Jeanne Schlegel ${ }^{2}$, Mathieu Morlighem $^{1}$, Eric Larour ${ }^{2}$, Jason P. Briner ${ }^{3}$, \\ Helene Seroussi ${ }^{2}$, and Lambert Caron ${ }^{2}$ \\ ${ }^{1}$ Department of Earth System Science, Croul Hall, University of California Irvine, Irvine, CA 92697-3100, USA \\ ${ }^{2}$ Jet Propulsion Laboratory, California Institute of Technology, 4800 Oak Grove Drive MS 300-323, Pasadena, \\ CA 91109-8099, USA \\ ${ }^{3}$ Department of Geology, University at Buffalo, Buffalo, NY 14260-4130, USA
}

Correspondence: Joshua K. Cuzzone (joshua.k.cuzzone@jpl.nasa.gov)

Received: 14 November 2018 - Discussion started: 5 December 2018

Revised: 20 February 2019 - Accepted: 24 February 2019 - Published: 14 March 2019

\begin{abstract}
Geologic archives constraining the variability of the Greenland ice sheet (GrIS) during the Holocene provide targets for ice sheet models to test sensitivities to variations in past climate and model formulation. Even as datamodel comparisons are becoming more common, many models simulating the behavior of the GrIS during the past rely on meshes with coarse horizontal resolutions ( $\geq 10 \mathrm{~km}$ ). In this study, we explore the impact of model resolution on the simulated nature of retreat across southwestern Greenland during the Holocene. Four simulations are performed using the Ice Sheet System Model (ISSM): three that use a uniform mesh and horizontal mesh resolutions of 20,10 , and $5 \mathrm{~km}$, and one that uses a nonuniform mesh with a resolution ranging from 2 to $15 \mathrm{~km}$. We find that the simulated retreat can vary significantly between models with different horizontal resolutions based on how well the bed topography is resolved. In areas of low topographic relief, the horizontal resolution plays a negligible role in simulated differences in retreat, with each model instead responding similarly to retreat driven by surface mass balance (SMB). Conversely, in areas where the bed topography is complex and high in relief, such as fjords, the lower-resolution models (10 and $20 \mathrm{~km})$ simulate unrealistic retreat that occurs as ice surface lowering intersects bumps in the bed topography that would otherwise be resolved as troughs using the higher-resolution grids. Our results highlight the important role that high-resolution grids play in simulating retreat in areas of complex bed topography, but also suggest that models using nonuniform grids can save com-
\end{abstract}

putational resources through coarsening the mesh in areas of noncomplex bed topography where the SMB predominantly drives retreat. Additionally, these results emphasize that care must be taken with ice sheet models when tuning model parameters to match reconstructed margins, particularly for lower-resolution models in regions where complex bed topography is poorly resolved.

\section{Introduction}

As the cryosphere community continues to make strides in understanding processes that govern variability of the present-day ice sheets, geologic proxies constraining past ice sheet change provide important clues as to how ice sheets may have responded to past climate change (Alley et al., 2010). Decades of research have led to the development of high-resolution geologic reconstructions that detail the spatial pattern and rate of retreat of the Greenland ice sheet (GrIS) over the last deglaciation as it evolved towards its present-day geometry (Weidick, 1968; Bennike and Bjorck, 2002; Young and Briner, 2015).

Southwestern Greenland is an area that experienced a large reduction in ice sheet extent. The ice margin retreated on the order of $150 \mathrm{~km}$ inland from the present-day coastline in response to warming during the early and middle Holocene (Briner et al., 2016). This landscape is punctuated 
by widely traceable moraine sequences (Weidick, 1968; Ten Brink and Weidick, 1974) that extend nearly $600 \mathrm{~km}$ throughout western Greenland and provide a constraint on the past retreat pattern of the GrIS in this region; the chronology of these moraines continues to be refined (Weidick et al., 2004, 2012; Young et al., 2013; Larsen et al., 2015; Lesnek and Briner, 2018). This history provides a benchmark for ice sheet model-data comparisons that will further enhance our understanding of the processes that influenced GrIS variability during the past while at the same time helping to highlight deficiencies in existing model frameworks.

Currently, ice sheet models simulating the evolution of the GrIS are focused either on long-term spin-ups over a glacial cycle (Huybrechts, 2002; Applegate, 2012) or its evolution during the last deglaciation (Tarasov and Peltier, 2002; Simpson et al., 2009; Lecavalier et al., 2014, 2017; Buizert et al., 2018). While many of these studies were primarily concerned with capturing the overall mass changes of the GrIS, one lineage of studies incorporated datasets of past GrIS change to develop a data-constrained model of its evolution over the last deglaciation. This was achieved by pairing an ice sheet model with a glacial isostatic adjustment and relative sea level model (Tarasov and Peltier, 2002; Simpson et al., 2009; Lecavalier et al., 2014, 2017). By incorporating data constraining the location of the GrIS beyond the presentday coastline, its vertical extent through time (i.e., ice thinning records), and records of relative sea level, the studies by Lecavalier et al. $(2014,2017)$ represent the most comprehensive model of GrIS change during the last deglaciation, with the results recently being compared against geologic archives of ice margin change (Larsen et al., 2015; Young and Briner, 2015; Sinclair et al, 2016).

While the models of Lecavalier et al. $(2014,2017)$ capture the timing and retreat pattern associated with the deglaciation in many locations well, large mismatches occur, particularly in southwestern Greenland and in areas where fast flow may have dominated (Young and Briner, 2015; Sinclair et al., 2016). The climatology used to force ice sheet models through time remains a primary source of uncertainty, and great strides have been made to improve our understanding of past climate history in Greenland through improved reconstructions of temperature (e.g., Kobashi et al., 2017; Lecavalier et al., 2017) and methods involving data assimilation of paleoclimate proxies with climate model output (Hakim et al., 2016; Buizert et al., 2018). Although recent experiments have investigated sensitivities to model formulation (Zekollari et al., 2017) and horizontal resolution over past climates (Zekollari et al., 2017; Seguinot et al., 2016; Golledge et al., 2012), testing the sensitivity of simulated ice retreat to the ice flow dynamics model (i.e., the level of complexity in its numerical approximations) and to model resolution, both in time and space, still remains an important area of research.

With regards to model setup, the use of coarse model resolutions ( $\geq 10 \mathrm{~km}$ grid spacing) might explain some of the model-data discrepancy (Larsen et al., 2015; Young and
Briner, 2015; Sinclair et al., 2016). Driven by how well models resolve subglacial topography, simulations of the presentday GrIS have shown an important dependence on model resolution for accurately simulating ice flow across Greenland (Greve and Herzfeld, 2013; Aschwanden et al., 2016). Dependence on model resolution also extends to modeling future ice mass loss, where higher-resolution models simulate more mass loss than models with lower resolutions (Greve and Herzfeld, 2013). Although some work has focused on model resolution and its impact on simulated mass flux from the GrIS for in the present and the future, how model resolution affects simulated retreat in paleo-ice-sheet modeling studies is not well constrained. Prior work demonstrates that low-resolution grids limit a model's ability to capture features such as ice streams and marine-terminating outlet glaciers (Aschwanden et al., 2016), which might be on the order of a few kilometers in width. Additionally, in landterminating portions of an ice sheet, low model resolution may lead to large jumps in the snowline, which ultimately can lead to large advances or retreats in the ice margin on the order of the model resolution (Young and Briner, 2015; Sinclair et al., 2016), and therefore limit the model's ability to capture smaller-scale ice marginal fluctuations (i.e., $\mathrm{km}$ scale).

In this study, we present results from regional ice sheet modeling experiments in southwestern Greenland during the Holocene using the three-dimensional thermomechanical Ice Sheet System Model (ISSM). We build on earlier efforts that focused on this ice sheet sector (e.g., Van Tatenhove et al., 1995). Ice model resolution is the primary target for assessment here, with four separate simulations being run, each with its own horizontal resolution ranging from 20 to $2 \mathrm{~km}$. In this study we do not attempt to obtain a perfect match between the simulated model retreat and that derived from the geologic reconstructions, as that requires further sensitivity studies that are not the current motivation for this work. Instead, since model resolution is a constraint that is typically not explored when studying the past due to the computational cost, in this study we aim to determine whether increased model resolution is worth the computation time for simulating past ice sheet retreat.

\section{Model description and setup}

\subsection{Ice sheet model}

We use the Ice Sheet System Model v4.13 (ISSM; Larour et al., 2012), a finite-element, thermomechanical ice sheet model. We choose the higher-order approximation of Blatter (1995) and Pattyn (2003), hereafter referred to as BP, to solve the momentum balance equations. Although recent work has used the higher-order approximation in simulations over past time periods (Zekollari et al., 2017), this ice flow approximation is still rarely used when simulating over pale- 


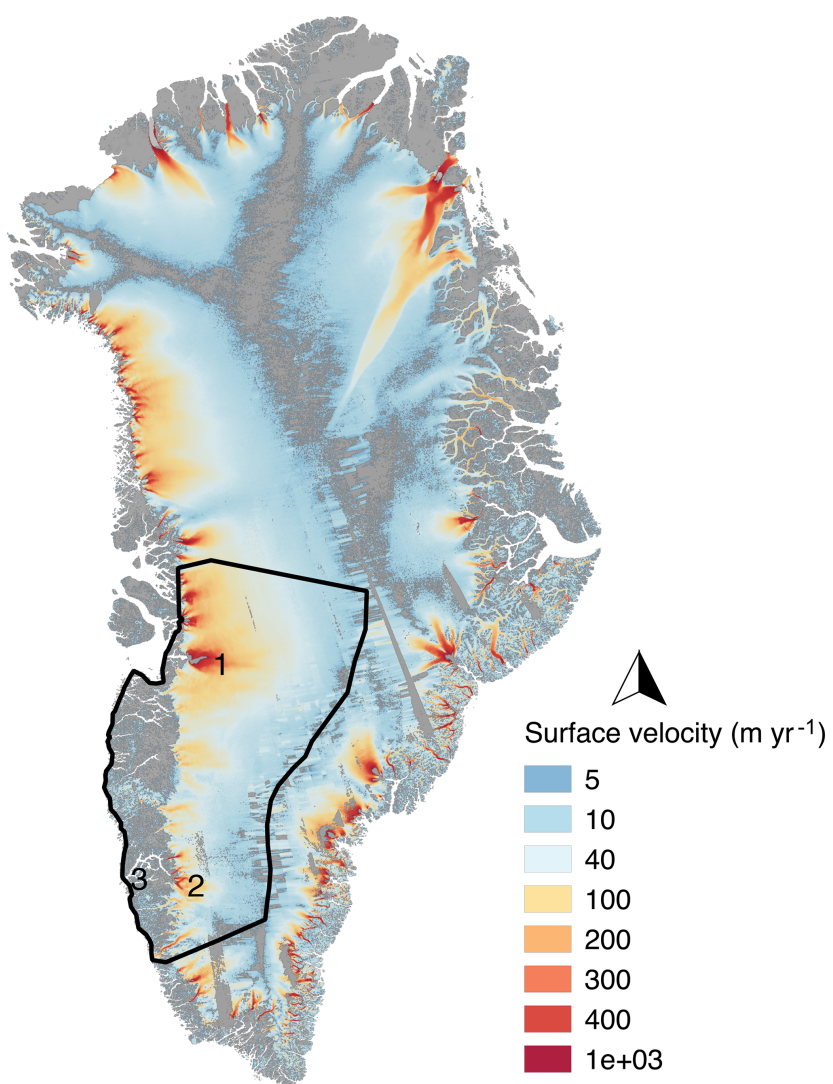

Figure 1. Present-day interferometric synthetic aperture radar (InSar) ice surface velocities from Rignot and Mouginot (2012) for the Greenland ice sheet. The regional model domain is highlighted in black. Marked locations correspond to (1) Jakobshavn Isbræ, (2) Kangiata Nunâta Sermia (KNS), and (3) Nuuk.

oclimate timescales. We use this approximation, however, as our choice is based upon representing the past dynamics of the ice sheet history as best as possible even though computational time is increased over conventional paleoclimate ice sheet models using the more common shallow ice approximation (SIA; Hutter, 1983).

The model domain for this study (Fig. 1) focuses on the southwestern region of Greenland, where geologic proxies detail Holocene ice retreat from the present-day coastline (Weidick, 1968; Ten Brink and Weidick, 1974). By constraining our domain to southwestern Greenland, the number of mesh elements within the model can be minimized when compared to modeling the entire GrIS, thus reducing the computational load. The model domain extends from the present-day coastline to the ice sheet divide. The southern and northern borders of the domain coincide with areas of minimal north-to-south across-boundary flow based upon present-day ice surface velocities from Rignot and Mouginot (2012). The associated boundary conditions used to drive the model are discussed in Sect. 2.6.

\subsection{Domain discretization}

Typically, prior paleoclimate ice sheet modeling efforts across Greenland have used uniform meshes with a horizontal resolution of $20 \mathrm{~km}$ (Simpson, 2009; Lecavalier, 2014); a more recent model used a $10 \mathrm{~km}$ horizontal mesh resolution (Buizert et al., 2018). For the following experiments, the first three models are generated using a uniform triangular grid with horizontal resolutions of 20,10 , and $5 \mathrm{~km}$. The fourth model (herein referred to as nonuniform) relies on anisotropic mesh adaptation, whereby the element size varies as a function of the bed topography (see Fig. S1 in the Supplement for visualization of mesh resolutions). The maximum horizontal mesh resolution is $15 \mathrm{~km}$ where gradients in the bed topography are smooth (primarily the interior bed over the domain) and becomes progressively finer in areas of high relief, with a minimum horizontal resolution of $2 \mathrm{~km}$ (mainly in fjord regions). The bed topography for each model is taken from BedMachine Greenland v3 (Morlighem et al., 2017) and is initialized with present-day ice surface elevation from the Greenland Ice Mapping Project digital elevation model of Howat et al. (2014). In Fig. 2, the corresponding bed height is shown for each model detailing the associated differences based on horizontal grid resolution. Generally, the bed topography is captured better using the higher-resolution mesh, with the nonuniform mesh (Fig. 2a) being able to best resolve valleys along the presentday coastline. The $5 \mathrm{~km}$ mesh captures the same general topographic features as the nonuniform mesh, albeit with less detail. At $10 \mathrm{~km}$, individual valleys become unresolved, particularly around Nuuk and Jakobshavn Isbræ (see Fig. 1 for locations). The $20 \mathrm{~km}$ model fails to capture any topographic features that would hold glacier outlets.

\subsection{Surface mass balance (SMB)}

We use the positive degree day method outlined in Tarasov and Peltier (1999) to construct the necessary accumulation and ablation history used to drive our ice sheet model during the past from monthly mean temperature and precipitation fields. The spatial monthly mean surface air temperature and precipitation climatology spanning the period 1980-2010 is taken from Box et al. (2013). The surface air temperatures are then scaled based upon isotopic variations in the Greenland Ice Core Project (GRIP) $\delta^{18}$ O record (Dansgaard et al., 1993) as follows:

$\delta \Delta T(t)=\delta\left({ }^{18} \mathrm{O}(t)+34.83\right)$,

where $d=2.4{ }^{\circ} \mathrm{C} \% o^{-1}$ (Huybrechts, 2002). Anomalies from Eq. (1) are applied to the present-day climatology to create a temperature forcing back through time. Precipitation rate changes $7.3 \%$ for every $1{ }^{\circ} \mathrm{C}$ of temperature change derived in Eq. (1) (Huybrechts, 2002). For the positive degree day scheme, snow melts first $\left(0.006 \mathrm{~m}^{\circ} \mathrm{C}^{-1} \mathrm{day}^{-1}\right)$ followed by bare ice $\left(0.0083 \mathrm{~m}^{\circ} \mathrm{C}^{-1} \mathrm{day}^{-1}\right)$ with allocation for the 

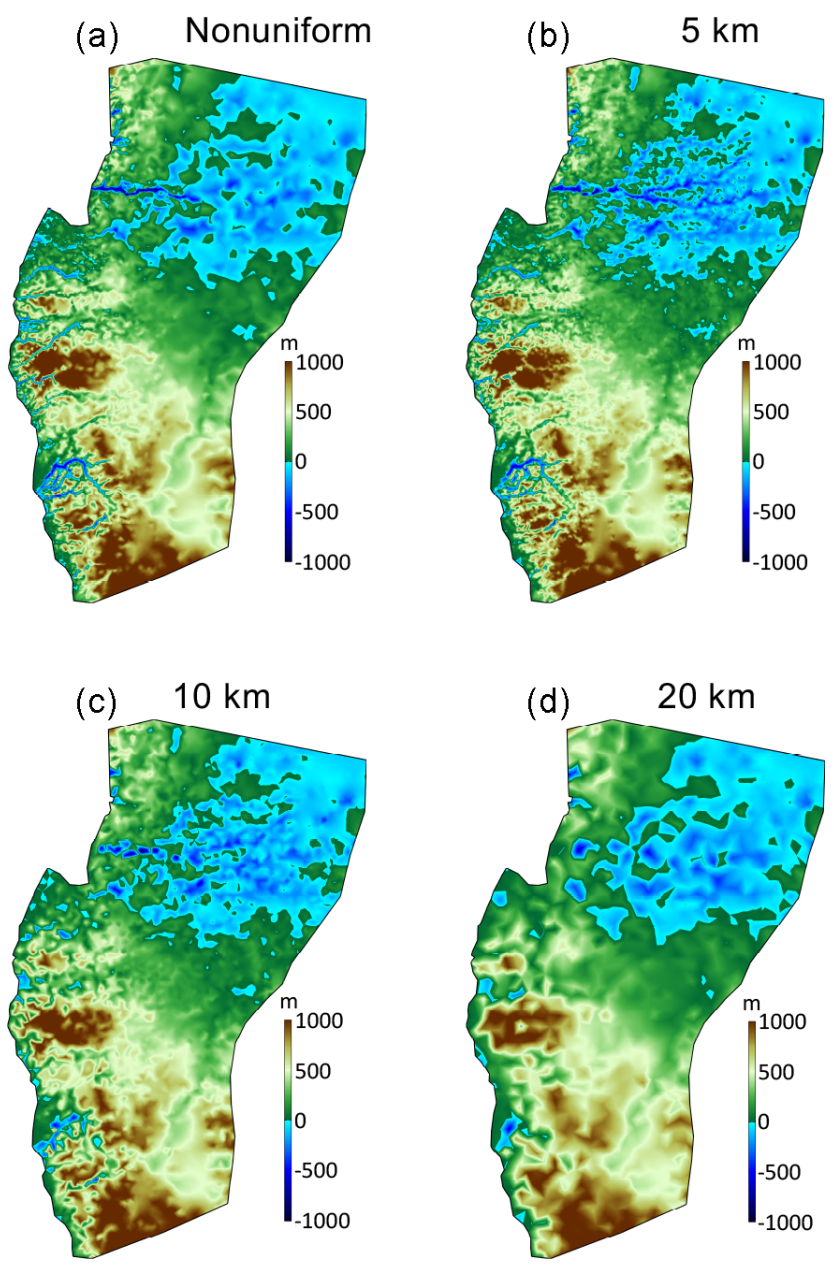

Figure 2. Associated bed topography maps for the nonuniform high-resolution mesh (a), uniform $5 \mathrm{~km}$ mesh (b), uniform $10 \mathrm{~km}$ mesh (c), and uniform $20 \mathrm{~km}$ mesh (d).

formation of superimposed ice included (see supplemental information in Le Morzadec et al., 2015). The temperature forcing is adjusted throughout the run using a lapse rate correction of $5^{\circ} \mathrm{C} \mathrm{km}^{-1}$ (Abe-Ouchi et al., 2007) to account for changes in ice surface height throughout the simulation, while elevation-dependent desertification is included (Budd and Smith, 1981) to ensure reduction in precipitation by a factor of 2 for every kilometer change in ice sheet surface elevation. Further details regarding the positive degree day and accumulation scheme implemented within the ISSM can be found in Le Morzadec et al. (2015).

\subsection{Thermal model and basal drag}

The thermal evolution of the ice is captured using an enthalpy formulation described in Aschwanden et al. (2012), which includes formulations for both temperate and cold ice. Transient surface air temperatures are imposed at the ice surface, while geothermal heat flux (from Shapiro and Ritzwoller,
2004) is applied at the base. The model contains five vertical layers, with spacing between layers decreasing modestly towards the base. To simulate the vertical distribution of temperature within the ice sheet, we rely on quadratic finite elements (i.e., $\mathrm{P} 1 \times \mathrm{P} 2$ ) along the $z$ axis as a means for our vertical interpolation. Details of the implementation and description of these higher-order vertical finite elements can be found in Cuzzone et al. (2018). Through using higherorder finite elements as a means for vertical interpolation, this method allows the ice sheet model to capture sharp thermal vertical gradients particularly at the bed, which is an improvement over conventional methods using a linear vertical interpolation, despite having fewer vertical layers. This ultimately limits the necessity for a large number of vertical layers in our ice model and therefore decreases computational load.

To capture spatial variations in sliding, the spatially varying basal drag coefficient $(k)$ in Eq. (2) is derived using inverse methods (Morlighem et al., 2010; Larour et al., 2012), providing the best match between modeled and interferometric synthetic aperture radar (InSAR) surface velocities (Rignot and Mouginot, 2012). This is performed independently for each model resolution.

$\tau_{\mathrm{b}}=-k^{2} N v_{\mathrm{b}}$,

where the $\tau_{\mathrm{b}}$ represents the basal stress, $N$ represents effective pressure, and $v_{\mathrm{b}}$ represents magnitude of the basal velocity.

Since the drag coefficient $(k)$ derived using this methodology is constrained to modern day, we adopt an approach based upon Hindmarsh and LeMeur (2001) and Greve (2005) to construct a spatially varying temperature-dependent scaling parameter $(\lambda)$ as a function of time.

$\lambda_{\mathrm{t}}=e^{\left(T_{\mathrm{b}(\text { modern })}-T_{\mathrm{b}(\mathrm{t})}\right) / \alpha}$,

where $T_{\mathrm{b} \text { (modern) }}$ is the basal temperature relative to pressure melting derived from a thermal steady-state computation for modern day (Seroussi et al., 2013), $T_{\mathrm{b}(\mathrm{t})}$ is the basal temperature relative to pressure melting at time $t$, and $\alpha$ is a constant scaling factor $\left({ }^{\circ} \mathrm{C}\right)$ often referred to as the sub-melt parameter (Hindmarsh and Le Meur, 2001). For these simulations $\alpha$ is set equal to 5. This number was chosen as it allows for a Last Glacial Maximum (LGM) GrIS simulated ice volume that is consistent with other ice sheet models that restrict ice extent to only present-day land (Applegate et al., 2012; Robinson et al., 2011). It is noted that values for this parameter lack a theoretical basis (Hindmarsh and Le Meur, 2001) and are often set to a value that prevents numerical instabilities from arising. Lastly, we scale the spatially varying basal drag coefficient $(k)$ as a function of $\lambda$, with maximum values capped at 300 to limit numerical instabilities that may arise from unreasonably large numbers:

$\tau_{\mathrm{b}}=-\lambda_{\mathrm{t}} \min \left(300, k^{2}\right) N v_{\mathrm{b}}$. 
For this approach, the basal stress $\left(\tau_{\mathrm{b}}\right)$ increases as the basal temperatures decrease relative to present day, with virtually no sliding occurring for high values of $k$. Conversely, the basal stress $\tau_{\mathrm{b}}$ decreases as basal temperatures increase, with high sliding for low values of $k$. Lastly, the ice hardness, $B$, is temperature dependent following the rate factors given in Cuffey and Paterson (2010, p. 75). We initialize $B$ by solving for a present-day thermal steady state (Cuzzone et al., 2018), while during forward runs $B$ evolves transiently through time.

\subsection{Experimental setup and boundary conditions for the regional domain}

We impose Dirichlet boundary conditions for the southern, northern, and ice divide boundaries, while the flux at the ice front in unconstrained. To create the necessary transient boundary conditions (ice thickness, temperature, and velocity), we perform a continental-scale GrIS simulation from the LGM (21500 years ago) to present day. This continentalscale simulation uses the BP ice flow approximation and is performed on a five-layer nonuniform mesh ranging in horizontal resolution from $3 \mathrm{~km}$ in areas of high present-day surface velocities to $20 \mathrm{~km}$ over the ice interior. It is performed using forcings and parameterizations similar to the regional model, as described in Sect. 2.3, 2.4, and 2.5.

For the regional model, we initialize the model with present-day geometry and run a relaxation centered at 12000 years ago, applying the appropriate interior ice boundary conditions of ice thickness, ice temperature, and the $x$ and $y$ component of ice velocity from the continentalscale GrIS simulation. This time period is chosen as the ice margin over southwestern Greenland was near or at the present-day coastline with the margin remaining stable during this interval (Young and Briner, 2015). The relaxation simulates 20000 years until the ice volume is in equilibrium. From here, the models are run transiently to present day. Since the ISSM currently does not have the capability of modeling solid earth viscoelastic deformation transiently, we include an offline time-dependent forcing that accounts for changes in relative sea level from glacial isostatic adjustment (Caron et al., 2018), which modifies the land area available for glaciation and impacts the presence of floating ice. While grounding line migration is simulated in these experiments, calving and submarine melting of floating ice are not included.

\subsection{Present-day thermal steady-state ice surface velocities}

The thermal steady-state ice surface velocities for the present day are shown for each individual model (Fig. 3). Generally, representation of faster ice flow along the coast improves with increasing resolution (i.e., increasing RMSE for lowerresolution models compared to Rignot and Mouginot, 2012).
This is primarily attributed to an improved representation of subglacial topography and ice thickness in the more highly resolved models (Aschwanden et al., 2016). As many of the outlet glaciers along this margin have troughs that are on the order of a few kilometers in width, the lower-resolution models $(10$ and $20 \mathrm{~km})$ do not fully resolve the fast-flowing ice streams of Jakobshavn Isbræ and outlets to its north. Outlet glaciers in the southern portion of the domain near Kangiata Nunâta Sermia (KNS) are also less well resolved in the lower-resolution models, although the general swath of higher velocities is captured well for most fast-flowing areas of the ice sheet when compared to the observations (Rignot and Mouginot, 2012). It is noted that the nonuniform mesh represents these faster flow features best when compared to observations in most regions due to its high resolution. Accordingly, the associated mass flux at the ice margin is representative of these differences in model resolution, with the 10 and $20 \mathrm{~km}$ models having an approximately $25 \%$ increase in mass flux $\left(\mathrm{GT} \mathrm{yr}^{-1}\right)$ compared to the observations, while the $5 \mathrm{~km}$ and nonuniform mesh have an approximately $5 \%$ to $9 \%$ increase in mass flux compared to observations.

\section{Results}

\subsection{Relaxed state at $12 \mathrm{ka}$}

The models are relaxed for 20000 years using a constant climate corresponding to $12 \mathrm{ka}$ (Fig. 4a). The four models simulate decreasing ice volume with decreasing model resolution; the $20 \mathrm{~km}$ model simulates approximately $6 \%$ less total ice volume than the nonuniform model. Ice surface velocities for the relaxed states (Fig. 5) depict the role of model horizontal resolution in capturing fjords and narrow outlets close to the model domain edge (i.e., present-day coastline). Generally, the two higher-resolution models (nonuniform and $5 \mathrm{~km}$ ) capture narrow, fast flow in these outlets, whereas the lower-resolution models simulate a more diffuse pattern in ice surface velocities. This is primarily the case in areas where the bed topography is better resolved in the higherresolution models and, therefore, confines the flow to narrow outlets. Ice velocities are reduced in the higher-resolution models for areas where the low bed topography that channels ice flow is interrupted by bumps and depressions in the bed. These features become less resolved in the lower-resolution models, with the $20 \mathrm{~km}$ model simulating much higher ice surface velocities in the Nuuk and Jakobshavn areas. Consistently, ice mass flux (in $\mathrm{GT} \mathrm{yr}^{-1}$ ) along the ice front (at the present-day coastline) is $34 \%$ and $14 \%$ higher than the nonuniform model for the 20 and $10 \mathrm{~km}$ model, respectively, which is the primary driver for lower simulated ice volumes for the relaxed $12 \mathrm{ka}$ state. 


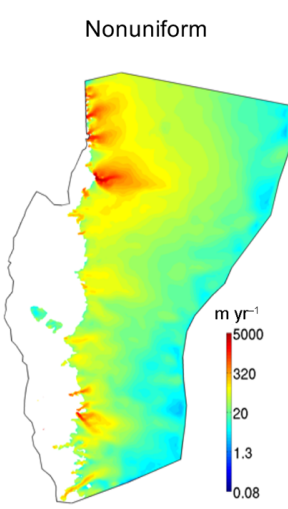

Nonuniform - Obs.

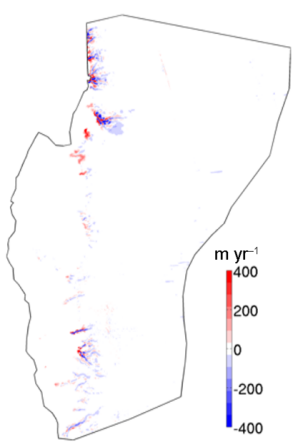

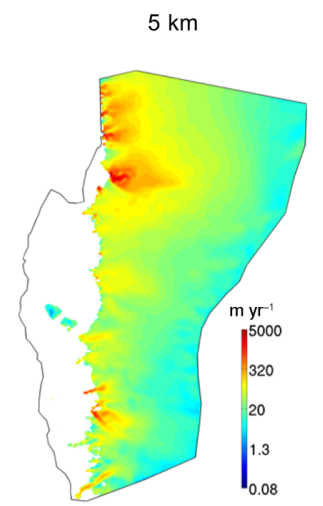

$5 \mathrm{~km}-\mathrm{Obs}$

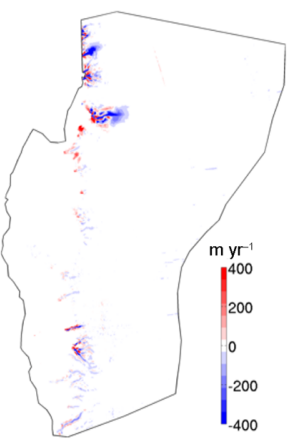

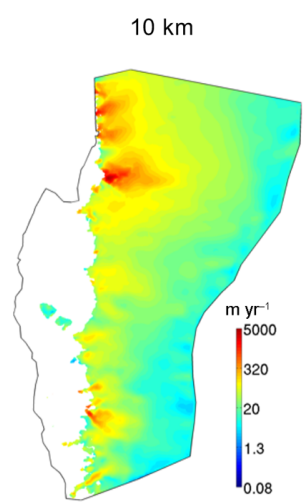

$10 \mathrm{~km}-$ Obs.

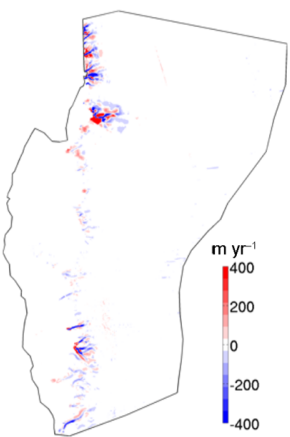

$20 \mathrm{~km}$

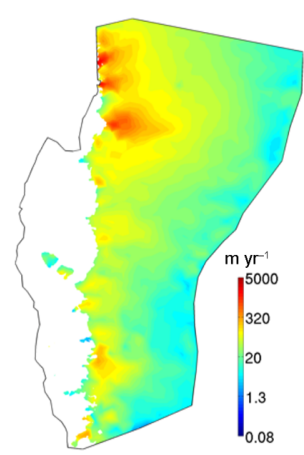

$20 \mathrm{~km}-$ Obs

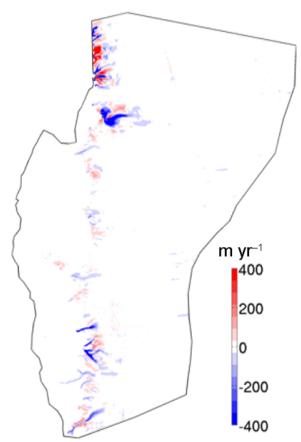

Figure 3. Present-day steady-state ice surface velocities for each individual model and their differences from observations (Rignot and Mouginot, 2012, shown in Fig. 1).

(a)

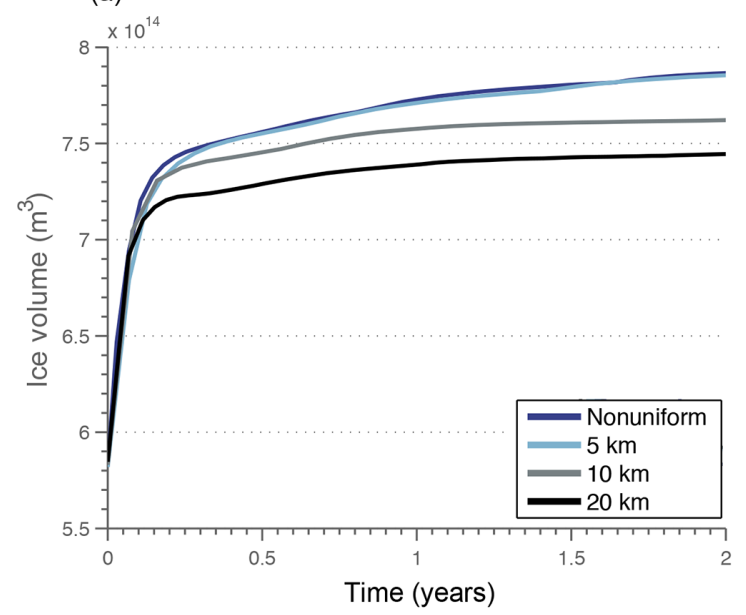

(b)

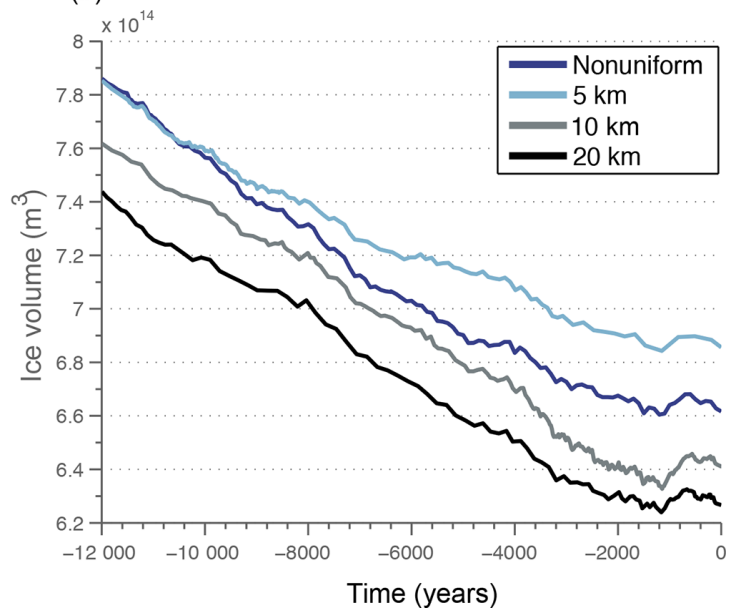

Figure 4. (a) Ice volume evolution for the $12 \mathrm{ka}$ constant climate relaxation. (b) Transient ice volume evolution for the simulations from $12 \mathrm{ka}$ to present day.

\subsection{Simulated ice volume ( $12 \mathrm{ka}$ to present day)}

The ice volume evolution for each model is shown in Fig. 4b. Generally, the 20 and $10 \mathrm{~km}$ models simulate the lowest present-day ice volumes, but they also begin at $12 \mathrm{ka}$ with lower ice volumes than the higher-resolution models. Each model follows a similar trend, with ice volume loss occurring between 12 and $1 \mathrm{ka}$, followed by an increase in ice volume to present day. 

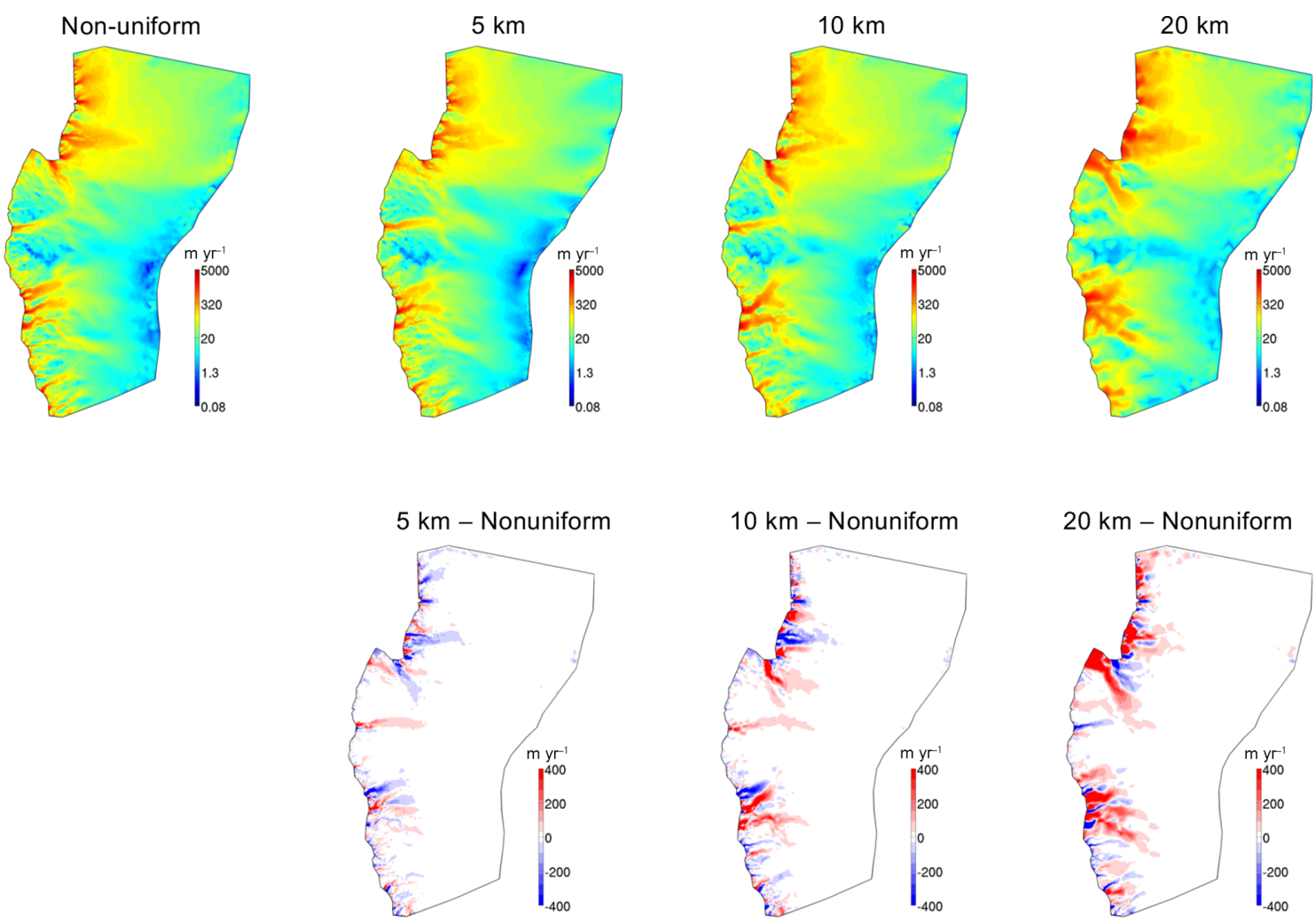

Figure 5. Relaxed ice surface velocities at $12 \mathrm{ka}$ for each model and differences from the nonuniform model.

\subsection{Large-scale simulated retreat}

Figure 6 shows the simulated extent at 11.2, 10.5, and $9.5 \mathrm{ka}$ for each model (middle and bottom row). All four models generally show ice retreat from the coastline occurring between 11.5 and $11.2 \mathrm{ka}$ in the northern portion of the model domain, whereas the ice margin experiences little to no retreat farther south. Despite differences in horizontal resolution, all models show a similar magnitude and pattern of retreat, with higher-resolution models depicting details in the ice margin similar in scale and sinuosity to the mapped pattern of moraines (see Fig. 6a for mapped moraines). Similarity between the magnitude and pattern of retreat also occurs at 10.5 and $9.5 \mathrm{ka}$ amongst all models. In contrast to the northern portion of the model domain, the southern portion features a simulated retreat that varies widely based upon model resolution. For example, at $10.5 \mathrm{ka}$ the higherresolution models ( $5 \mathrm{~km}$ and nonuniform) exhibit little retreat from the coastline, whereas the 10 and $20 \mathrm{~km}$ models show upwards of 50-60 km of retreat. Differences in retreat between the higher- and lower-resolution models are further seen at $9.5 \mathrm{ka}$. Over land-terminating portions in the southern area, the modeled ice margin retreats similarly within all models; however, in the fjord regions (e.g., inland of Nuuk), only the 10 and $20 \mathrm{~km}$ models show ice margin retreat (of $\sim 50-70 \mathrm{~km})$, whereas the higher-resolution models exhibit no ice margin retreat.

\subsection{Simulated retreat ( $12 \mathrm{ka}$ to present day) - along flow lines}

To better illustrate simulated ice margin behavior through time, we analyze ice retreat along five specific flow lines (A through E; Fig. 7) across the domain. In Fig. 7, ice retreat along flow line A is shown for each model. All models show a similar trend with the highest retreat rate (upwards of $50-100 \mathrm{~m} \mathrm{yr}^{-1}$ ) occurring between approximately 11.5 and $10 \mathrm{ka}$. Between $\sim 10 \mathrm{ka}$ and the present, all simulated ice margins generally reside within $10 \mathrm{~km}$ of the present-day ice margin. The retreat history simulated by the 10 and $20 \mathrm{~km}$ models exhibits a relatively stable ice margin for much of this period, whereas the higher-resolution models (i.e., nonuniform and $5 \mathrm{~km}$ ) depict an ice margin that is characterized by higher-frequency variability on the order of $5-8 \mathrm{~km}$. The retreat history along flow lines B and C is consistent in timing and pattern to flow line A (shown in Figs. S2 and S3).

Differences in the bed topography between the four models reflect model resolution, with higher-resolution models capturing topography closer to reality (Fig. 7). Nevertheless, the bed topography along the flow line $\mathrm{A}$ is similar among the different models owing to the low-relief topography in this region. The low-angle ice surface responds to surface 
(a)
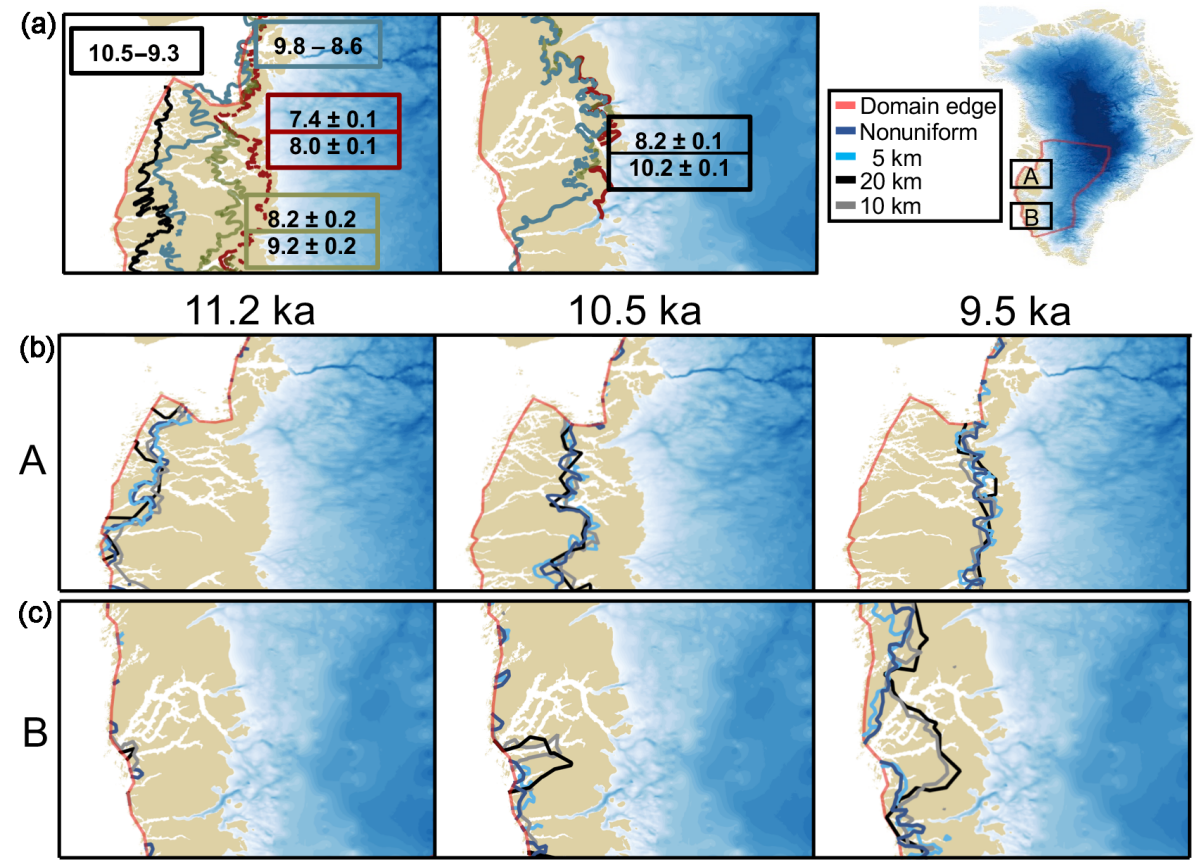

Figure 6. (a) Mapped moraines and the existing chronology of ice retreat over the northern and southern portion of our domain. The mapped moraines and corresponding ages of retreat were taken from Lesnek and Briner (2018). (b, c) Simulated ice sheet margin for the different model resolutions shown over locations in the northern (b) and southern (c) domain. The present-day ice thickness is shown, derived from Morlighem et al. (2017) and Howat et al. (2014).

(a)
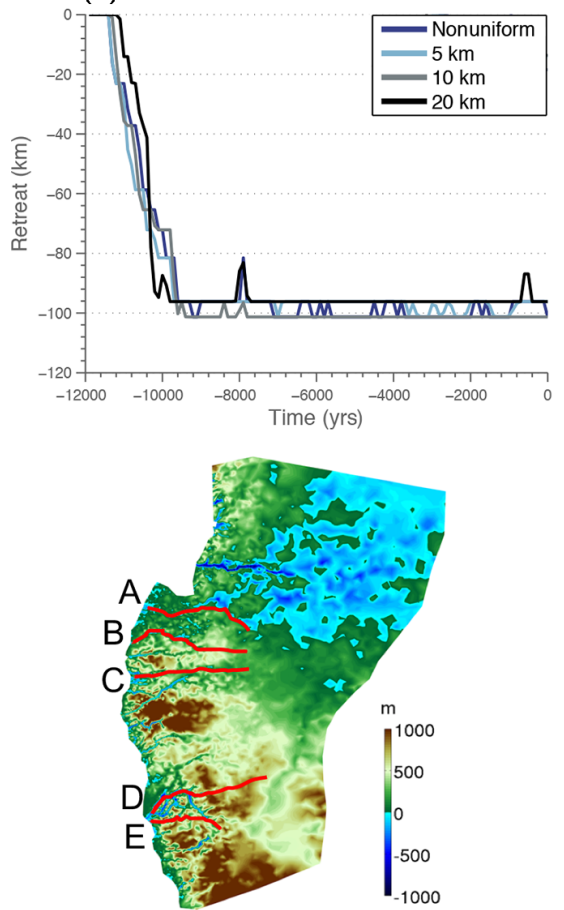

(b)

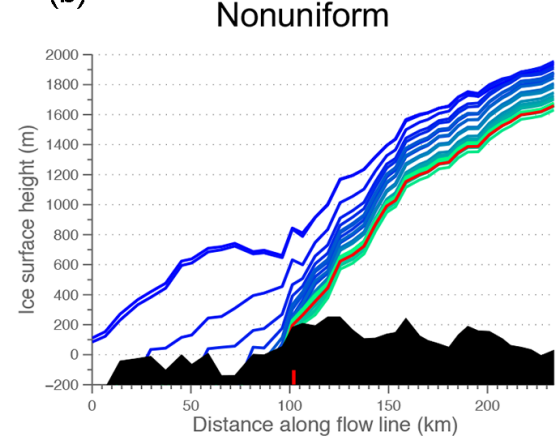

$10 \mathrm{~km}$

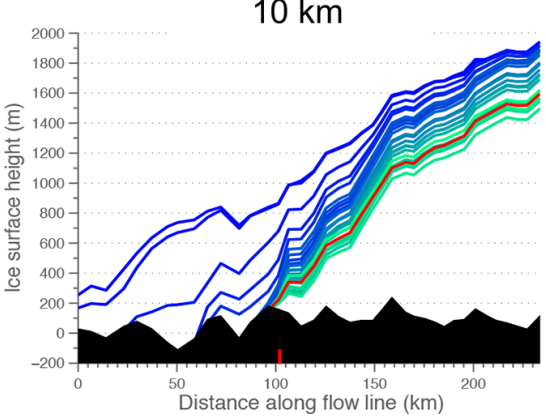

$5 \mathrm{~km}$

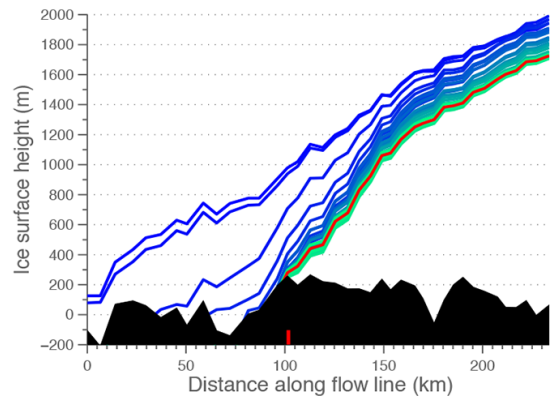

$20 \mathrm{~km}$

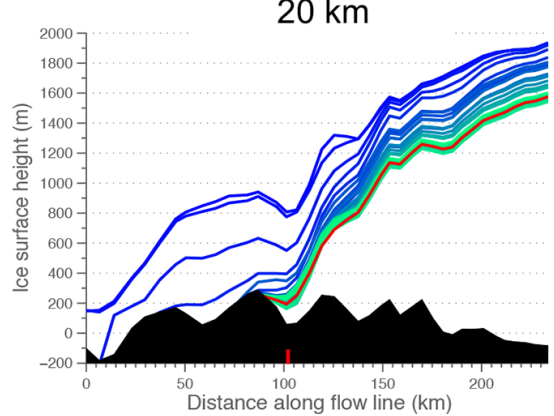

Figure 7. (a) Simulated retreat along flow line A for each model. (b) Ice surface profiles shown at 500-year intervals (blue: older; green: younger; the red line indicates the simulated present-day ice surface profile), with the underlying bed topography (filled black area). The red tick mark on the $x$ axis denotes the present-day ice margin (Howat et al., 2014). Readers should refer to this figure for locations of flow lines used in this study. 
melt similarly among the four models along flow line A (see Fig. S2 for surface temperature and SMB along flow lines) and is likely why the retreat history is similar. Along flow line B (Fig. S3), bed topography in all models exhibits increasing elevation into the ice sheet interior. Whereas the nonuniform and $5 \mathrm{~km}$ models capture a trough between 30 and $120 \mathrm{~km}$ along the flow line, this feature is subtle in the $10 \mathrm{~km}$ model and nonexistent in the $20 \mathrm{~km}$ model. Similar to flow line A, however, the simulated retreat in flow line B is similar amongst the different models both in rate and magnitude of retreat. Generally, the ice margins exhibit retreat forced primarily through surface lowering in response to negative SMB (Fig. S2) because the ice margin retreats similarly through areas of varying bed topography. At approximately $150 \mathrm{~km}$ along the flow line, the ice retreats into an area with higher bed topography, and the ice surface profiles become steeper, thereby raising the equilibrium line altitude (ELA) and stabilizing the ice margin. Along flow line C (Fig. S4), the bed topography for the nonuniform and $5 \mathrm{~km}$ model is characterized by low elevations at the beginning and end of the flow line, with a peak in elevation in the middle, while the 10 and $20 \mathrm{~km}$ models exhibit a more consistent bed elevation along the flow line. The upward slope of the bed for the nonuniform and $5 \mathrm{~km}$ model tends to slow the retreat of the ice margin along flow line $\mathrm{C}$ during the early Holocene, although differences between the 10 and $20 \mathrm{~km}$ models are not dramatic. After $8 \mathrm{ka}$, ice retreat stabilizes in all models, similar to flow lines $\mathrm{A}$ and $\mathrm{B}$, although the nonuniform and $5 \mathrm{~km}$ models exhibit marginal ice fluctuations on the order of $5-8 \mathrm{~km}$.

In the southern portion of the domain, the fjords within the Nuuk region dominate the landscape. The ice margin in flow line D (Fig. 8) remains fixed for the entire simulation in the nonuniform and $5 \mathrm{~km}$ model simulations. In contrast, both the 10 and $20 \mathrm{~km}$ models depict retreat at $\sim 9.5 \mathrm{ka}$, after which the $10 \mathrm{~km}$ model quickly stabilizes and the $20 \mathrm{~km}$ model exhibits variability up to present day. All models fail to simulate a present-day ice margin that comes close to today's observed ice margin (Fig. 8). The lower-resolution models simulate retreat in this region on the order of 30 to $50 \mathrm{~km}$, which is controlled primarily by the bed topography. In reality, a trough extends much of the distance along this flow line, which is captured well by both the nonuniform and $5 \mathrm{~km}$ mesh, where depths reach $\sim 500 \mathrm{~m}$ below sea level. Consequently, the nonuniform and $5 \mathrm{~km}$ models are better able to capture the stress balance and mass transport, as they simulate more realistic ice flow and delivery of ice mass to the margin in this region. In the $10 \mathrm{~km}$ model, surface lowering intersects a bed bump that is above sea level at approximately $40 \mathrm{~km}$ along flow line D. Inland of this rise in the bed, the $10 \mathrm{~km}$ model bed contains a shallow trough, which is capable of sustaining the ice margin throughout the remainder of the simulation. The $20 \mathrm{~km}$ model lacks any clear trough and instead captures a significant rise in the bed topography at $70 \mathrm{~km}$ along the flow line, where the other models resolve a trough. As the ice surface lowers along flow line D, it becomes increasingly influenced by this bed feature. Due to the upward slope and horizontal top of this bed feature, the margin varies in response to the high-frequency climate variability during the Holocene (Fig. S2).

Flow line E (Fig. S5) follows a narrow and shallow trough south of flow line D. This shallow trough is only captured completely in the nonuniform model, although the $5 \mathrm{~km}$ model captures low topography along the ice margin. In the 10 and $20 \mathrm{~km}$ models there is no indication of a trough and instead the bed topography is high and generally flat. Similar to flow line D, downwasting via negative SMB (Fig. S2) drives ice retreat in the 10 and $20 \mathrm{~km}$ models. Because the nonuniform mesh captures a trough along flow line E, delivery of ice mass to the margin continues through the Holocene, stabilizing the ice margin position despite surface lowering through negative SMB.

\section{Discussion}

We find that model resolution plays a negligible role in the simulated ice margin history in the northern portion of our domain along flow lines A, B, and C. In the southern domain along flow lines $\mathrm{D}$ and $\mathrm{E}$, however, model resolution plays a large role in the simulated ice margin history.

\subsection{Retreat within the northern domain}

In the northern portion of our model domain, geologic archives indicate retreat from the coast occurred between 12 and 11 ka (Kelly et al., 2015; Young and Briner, 2015; Fig. 6a), which is generally consistent with our simulations regardless of resolution. The subsequent retreat in all models towards the present-day ice margin is also generally consistent with the geologic reconstructions of ice margin retreat in this region (Fig. 6b and c). Van Tatenhove et al. (1996) provide one of the earliest ice sheet model-data comparisons for this region (around flow line C) during the last deglaciation. Van Tatenhove et al. (1996) compared three different ice sheet models ranging in resolution from 20 to $40 \mathrm{~km}$ to ice margin reconstructions constrained by radiocarbon ages from the region and indicated that model resolution played little role in the inter-model retreat differences. Van Tatenhove et al. (1996) pointed to the strong governing role of SMB in this region with little influence from ice streams. Likewise, simulations from the $20 \mathrm{~km}$ resolution model of Lecavalier et al. (2014) show reasonable agreement in the retreat across this region when compared to geologic reconstructions. Our results indicate that the bed topography in this region is well represented among the different models, despite their differences in resolution, and thus simulated ice margin history faithfully responds to SMB forcing and is not complicated by ice flow adjustments to underlying topography. However, one feature that stands out in the higher-resolution models 
(a)

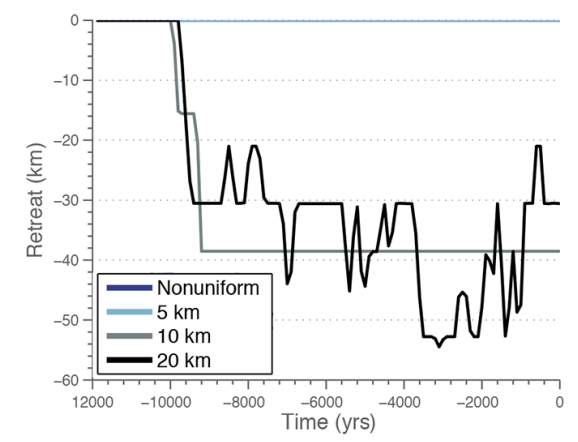

(b)

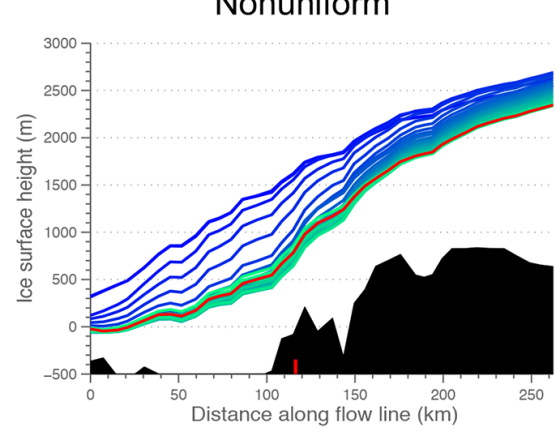

$10 \mathrm{~km}$

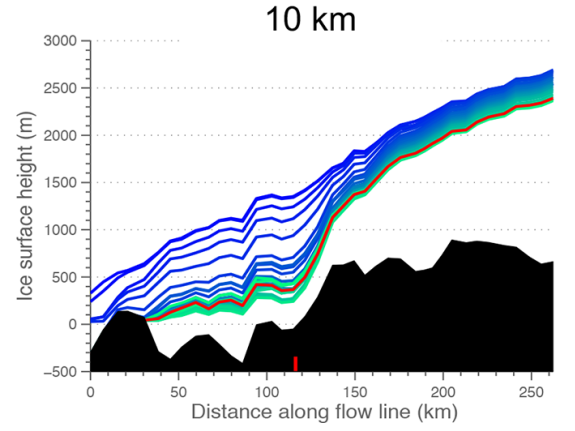

$5 \mathrm{~km}$

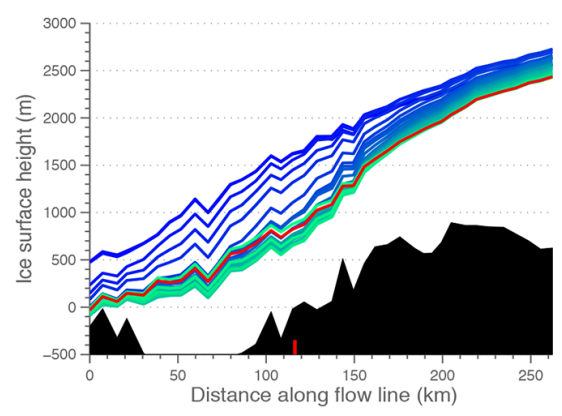

$20 \mathrm{~km}$

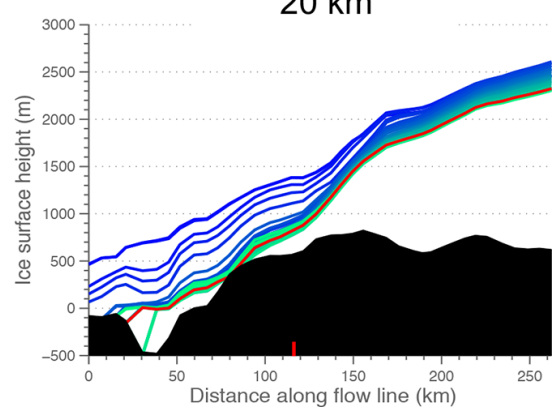

Figure 8. Same as in Fig. 7 but for flow line D.

( $5 \mathrm{~km}$ and nonuniform) is the presence of high-frequency ice marginal fluctuations on the order of 5-8 km (Figs. 7, S3, S4). The geologic record indicates that small-scale marginal fluctuations are likely responsible for the moraine record and seem to be related to high-frequency variability in temperature (e.g., Young et al., 2013). Thus, models capable of capturing small-scale fluctuations in the ice margin history are valuable for comparing with geologic constraints of past ice sheet change. The inability of lower-resolution models to capture these features has been highlighted in previous work (Van Tatenhove et al., 1996; Larsen et al., 2015) and hampers data-model comparisons.

\subsection{Retreat within the southern domain}

In the southern portion of the model domain, fjord systems provide a different bed setting than in the north, presenting a significant challenge for modeling ice margin change. Deep and narrow troughs up to $500 \mathrm{~m}$ below sea level and 3-5 km wide seemingly played an important role in governing ice margin retreat. Many geologic archives that constrain past ice margin variability in this region (Sinclair et al., 2016) reveal rapid deglaciation from the present-day coastline to near the present-day margin at $\sim 10 \mathrm{ka}$ (e.g., Larsen et al., 2014; Fig. 6a). None of our experiments match the geologic observations.

Our simulated ice retreat is highly dependent on model resolution in this area because the different models repre- sent the bed topography quite differently. For example, only the nonuniform and $5 \mathrm{~km}$ models capture the deep fjords, whereas the 10 and $20 \mathrm{~km}$ models have unrealistic bed features that end up driving retreat (Figs. 8 and S5). Our simulations do not include calving or submarine melting, and, therefore, each model's simulated ice surface responds similarly to negative SMB. However, the ability of the high-resolution models to resolve the narrow and deep fjords allows the ice margin to persist, as the stress balance and mass transport is well captured. Since the fjords are not well represented in the low-resolution models, there is lower delivery of ice mass to the margin, and the simulated retreat is driven as the ice surface lowers and intersects elevated bump artifacts in the bed topography. While none of the models capture the timing or amount of retreat accurately, the high-resolution models in this case perform the worst, capturing negligible retreat. The rapid ice margin recession recorded by the geologic reconstructions in this marine-dominated region probably highlight the influence of calving and enhanced submarine melting of floating ice, neither of which are included in our model simulations. The lack of submarine melting, in particular, may lead to the model-data mismatch; available evidence (e.g., Dyke et al., 2014) supports influence of the warm Irminger Current during the early Holocene, which likely penetrated fjords up to the ice margin. 


\subsection{Different drivers of retreat}

There are stark differences in processes affecting retreat of the land-dominated ice margin (i.e., SMB in the northern section of the model domain) and the marine-dominated ice margin (i.e., calving and submarine melt in the southern portion of the domain). These different drivers of ice margin change also affect different sectors of the contemporary GrIS (Sole et al., 2008; Straneo and Heimbach, 2013). Our results highlight that in areas of simple, low-relief bed topography, SMB drives the simulated retreat with few differences existing between models of varying spatial resolution. Therefore, efforts that attempt to match geologic reconstructions will be better served by focusing on representing SMB as accurately as possible. Conversely, in areas with complex, high-relief bed topography, such as in fjord settings, models that are unable to capture the deep and narrow troughs may unreasonably simulate retreat (see Åkesson et al., 2018). Anisotropic mesh capabilities play an important role in allowing a model to adjust its resolution spatially while using computer time efficiently.

For low-resolution models, care must be taken when attempting to capture the reconstructed retreat in areas of complex bed topography. For example, in order to satisfy relative sea level records used to constrain an ice sheet model of the GrIS, Lecavalier at al. (2014) artificially increased middle Holocene temperatures used to drive the ice sheet model. Although this resulted in a simulated ice margin history consistent with available geologic records, it is noted that such external forcings may drive unphysical retreat in areas of complex bed topography that may otherwise have been driven by ice dynamics. Another consideration is the regional setting presented here. Since these experiments are focused on the southwestern GrIS, an area that may be relatively topographically uniform, we expect the results of the marine-influenced region in the southern part of our domain to be most relevant for other portions of the GrIS, in particular in eastern Greenland where fjords dominate the landscape (Morlighem et al., 2017).

\subsection{Model limitations}

When simulating the retreat of the southwestern GrIS, our choice of climate forcing, using the GRIP $\delta^{18} \mathrm{O}$ record (Dansgaard et al., 1993), follows what has been a cornerstone in forcing Greenland ice sheet modeling over the paleoclimate record (Huybrechts, 2002; Greve et al., 2011; Applegate et al., 2012). This approach has been adjusted in Tarasov and Peltier (2002), Simpson et al. (2009) and Lecavalier et al. (2014) by synthetically increasing Holocene temperatures, with more recent simulations of the deglaciation of Greenland making use of more recent temperature proxy reconstructions that are better constrained throughout Greenland (Lecavalier et al., 2017; Buizert et al., 2018). Nevertheless, using a single, scaled paleoclimate record from Summit ignores the more likely history of a spatiotemporally variable climate history spanning the Holocene around Greenland (cf. Vinther et al., 2009). In any case, since the traditional approach (i.e., the GRIP $\delta^{18} \mathrm{O}$ scaling) assumes that the spatial variability in temperature and seasonality remains fixed to modern day, our results cannot fully reconcile how changes in the magnitude of warming and spatial variation of that warming affects our results. Additionally, the scaling of the basal friction coefficient introduces some uncertainties particularly when considering the temperature forcing throughout the simulation. Our method for scaling the basal friction coefficient through time follows a common approach used in many modeling studies over paleoclimate timescales (Hindmarsh and LeMeur, 2001; Greve ,2005). For these simulations, the evolution of the basal temperatures through time depends on the surface temperature forcing which is derived from the GRIP $\delta^{18} \mathrm{O}$ scaling. Therefore, changes to the surface temperature forcing can impact the evolution of the basal temperatures over time, which ultimately affects the ice sliding following this approach. This model limitation falls within the bounds of current ice sheet modeling efforts, whereby a lack of physically based basal sliding parameterizations exist. Despite this limitation, the conclusions presented here remain unaffected.

Although these simulations have no reasonable representation of calving, the results do indicate that models with a resolution of $10 \mathrm{~km}$ or greater would be likely unable to address calving processes in fjords, as typical fjord width is $\leq 10 \mathrm{~km}$. In ice sheet models, calving is often related to water depth, considering past changes in eustatic and relative sea level (Huybrechts, 2002; Simpson et al., 2009; Lecavalier et al., 2014). Although the high-resolution models presented here do capture the narrow fjords, implementation of a calving scheme would currently be computationally intensive. One possibility for future work would be to force the model with high submarine basal melt rates as a proxy for calving, as done in Åkesson et al. (2018). Submarine melt has been shown to be an important mechanism driving both contemporary ice mass loss (Rignot, 2010) and past GrIS variability on glacial and interglacial timescales (Bradley et al., 2018; Tabone et al., 2018). Although few constraints do exist detailing past variations in ocean temperature for the Labrador Sea (Winsor et al., 2012; Gibb et al., 2015) and Disko Bay (Jennings et al., 2006), applying submarine melt rates to marine termini throughout our model domain would not be possible without significant uncertainty. Additionally, in applying basal melting to floating ice, it is uncertain whether $2 \mathrm{~km}$ resolution would be sufficient to accurately capture grounding line migration, as recent research (Seroussi and Morlighem, 2018) suggests that resolutions of $1 \mathrm{~km}$ or higher are often necessary to match present-day fluctuations. 


\section{Conclusions}

We investigated how ice sheet model resolution influences the simulated Holocene retreat of the southwestern GrIS using the ISSM. Our focus on the southwestern GrIS is driven by two factors: first, the regional approach allowed for modeling at a high resolution (for the nonuniform and $5 \mathrm{~km}$ mesh) while minimizing computational costs that would increase significantly while running a GrIS-wide simulation. Second, the southwestern GrIS is an area where geologic archives indicate the ice sheet underwent large-scale and relatively wellknown retreat during the Holocene.

The results presented here indicate that model resolution has a selective influence in the simulated retreat over southwestern Greenland during the Holocene. In areas where the bed topography is relatively simple, low-relief, and free from marine influence, model resolution plays an insignificant role in influencing the pattern and rate of retreat. Here, models with different resolutions respond similarly to SMB-driven retreat. On the other hand, in areas with complex and highrelief bed topography, such as deep troughs and fjords, the low-resolution models lead to unrealistic retreat. As all models in these simulations only respond to surface melt and, therefore, ice surface lowering (and no mass loss via calving or submarine melt), the low-resolution models (10 and $20 \mathrm{~km}$ ) simulate ice retreat driven purely as a consequence of incorrectly capturing the bed geometry. As one example, ice surface lowering in these models intersects bed bumps that would otherwise be resolved as a trough in higher-resolution models.

Our results imply that computational resources can be saved when modeling certain portions of the GrIS. Conversely, the results also highlight the importance of model resolution in areas of complex topography. Ice sheet models using a nonuniform mesh can adapt grids to fit these constraints while using computation time efficiently. However, for models using uniform fine-scale meshing, resolving such features becomes computationally difficult, especially over long paleoclimate timescales. As ice sheet models sometimes rely on the geologic record for validation, care must be taken in evaluating model-data misfits. In areas of complex topography, over-tuning of model parameters or climatology may occur in low-resolution models that seek to match the reconstructed margin. We suggest that increased model resolution is critical in regions dominated by fjords (e.g., southeastern Greenland).

Future work with the ISSM will focus on using a model that has a lower resolution in areas driven mainly by SMB and a higher resolution in areas influenced by dynamical ice processes using nonuniform mesh capabilities. Future work will also seek to evaluate the sensitivity of using improved climate forcings (Hakim et al., 2016; Buizert et al., 2018), better representations of ice dynamics (calving and submarine melt), and more quantitative comparisons to improved ice margin reconstructions.
Data availability. The simulations performed for this paper made use of the open-source Ice Sheet System Model (ISSM) and are publicly available at https://issm.jpl.nasa.gov/ (last access: 14 February 2019, Larour et al., 2012).

Supplement. The supplement related to this article is available online at: https://doi.org/10.5194/tc-13-879-2019-supplement.

Author contributions. All authors contributed to the discussion of the results in this paper. JKC led the numerical modeling carried out in this paper, with help from NJS and MM. JKC, NJS, and MM designed the experiments presented in this paper. NJS and JKC led the development of the friction scaling implemented in these simulations. MM, HS, and JKC led the development and implementation of the higher-order finite elements used in the thermal modeling for these simulations. JKC and JPB led comparison of the simulated margin history with the geologic record of past margin migration. LC provided output constraining past relative sea level variations.

Competing interests. The authors declare that they have no conflict of interest.

Acknowledgements. Funding for this study was provided by the National Science Foundation Grant ARC no. 1504230. We would like to thank Surendra Adhikari and Mark Richardson for their helpful discussion and Alia Lesnek for providing the geologic data constraining past ice history. Lastly, we thank Andreas Vieli and the two reviewers, Alexander Robinson and Julien Seguinot for their constructive feedback regarding this work.

Edited by: Andreas Vieli

Reviewed by: Alexander Robinson and Julien Seguinot

\section{References}

Abe-Ouchi, A., Segawa, T., and Saito, F.: Climatic Conditions for modelling the Northern Hemisphere ice sheets throughout the ice age cycle, Clim. Past, 3, 423-438, https://doi.org/10.5194/cp-3423-2007, 2007.

Åkesson, H., Morlighem, M., Nisancioglu, K. H., Svendsen, J. J., and Mangerud, J.: Atmosphere-driven ice sheet mass loss paced by topography: Insights from modelling the south-western Scandinavian Ice Sheet, Quaternary Sci. Rev., 195, 32-47, https://doi.org/10.1016/j.quascirev.2018.07.004, 2018.

Alley, R. B., Andrews, J. T., Miller, G. H., White, J. W. C., BrighamGrette, J.,Clarke, G. K. C., Cuffey, K. M., Fitzpatrick, J. J., Muhs, D. R., Funder, S., Marshall, S. J., Mitrovica, J. X., OttoBliesner, B. L., and Polyak, L.: History of the Greenland Ice Sheet: Paleoclimatic insights, Quaternary Sci. Rev., 29, 17281756, https://doi.org/10.1016/j.quascirev.2010.02.007, 2010.

Applegate, P. J., Kirchner, N., Stone, E. J., Keller, K., and Greve, R. An assessment of key model parametric uncertainties in projec- 
tions of Greenland Ice Sheet behavior, The Cryosphere, 6, 589606, https://doi.org/10.5194/tc-6-589-2012, 2012.

Aschwanden, A., Bueler, E., Khroulev, C., and Blatter, H.: An enthalpy formulation for glaciers and ice sheets, J. Glaciol., 58, 441-457, https://doi.org/10.3189/2012JoG11J088, 2012.

Aschwanden, A., Fahnestock, M. A., and Truffer, M.: Complex Greenland outlet glacier flow captured, Nat. Commun., 7, 10524, https://doi.org/10.1038/ncomms10524, 2016.

Bennike, O. and Björck, S.: Chronology of the last recession of the Greenland ice sheet, J. Quaternary Sci., 17, 211-219, 2002.

Blatter, H.: Velocity and stress-fields in grounded glaciers: A simple algorithm for including deviatoric stress gradients, J. Glaciol., 41, 333-344, https://doi.org/10.3189/S002214300001621X, 1995.

Box, J. E.: Greenland ice sheet mass balance reconstruction. Part II: Surface mass balance (1840-2010), J. Clim., 26, 6974-6989, https://doi.org/10.1175/JCLI-D-12-00518.1, 2013.

Bradley, S. L., Reerink, T. J., van de Wal, R. S. W., and Helsen, M. M.: Simulation of the Greenland Ice Sheet over two glacialinterglacial cycles: investigating a sub-ice-shelf melt parameterization and relative sea level forcing in an ice-sheet-ice-shelf model, Clim. Past, 14, 619-635, https://doi.org/10.5194/cp-14619-2018, 2018.

Briner, J. P., McKay, N., Axford, Y., Bennike, O., Bradley, R. S., de Vernal, A., Fisher, D. A., Francus, P., Fréchette, B., Gajewski, K. J., Jennings, A. E., Kaufman, D. S., Miller, G. H., Rouston, C., and Wagner, B.: Holocene climate change in Artic Canada and Greenland, Quaternary Sci. Rev., 147, 340-364, 2016.

Budd, W. F. and Smith, I.: The growth and retreat of ice sheets in response to orbital radiation changes, Sea Level, Ice, and Climatic Change, 131, 369-409, 1981.

Buizert, C., Kiesling, B. A., Box, J. E., He, F., Carlson, A. E., Sinclair, G., and DeConto, R. M.: Greenland-Wide Seasonal Temperatures During the Last Deglaciation, Geophys. Res. Lett., 45, 1905-1914, https://doi.org/10.1002/2017GL075601, 2018.

Caron, L., Ivins, E. R., Larour, E., Adhikari, S., Nilsson, J., and Blewitt, G.: GIA model statistics for GRACE hydrology, cryosphere and ocean science, Geophys. Res. Lett., 45, 22032212, https://doi.org/10.1002/2017GL076644, 2018.

Cuffey, K. M. and Paterson, W. S. B.: The physics of glaciers, 4th edn., Butterworth-Heinemann, Oxford, 2010.

Cuzzone, J., Morlighem, M., Larour, E., Schlegel, N., and Seroussi, H.: Implementation of higher-order vertical finite elements in ISSM v4.13 for imporved ice sheet flow modeling over paleoclimate timescales, Geosci. Model Dev., 11, 1683-1694, https://doi.org/10.5194/gmd-11-1683-2018, 2018.

Dansgaard, W., Johnsen, S. J., Clausen, H. B., Dahl-Jensen, D., Gunderstrup, N. S., Hammer, C. U., Steffensen, J. P., Sveinbjörnsdottir, A., Jouzel, J., and Bond. G.: Evidence for general instability of past climate from a $250-\mathrm{kyr}$ ice-core record, Nature, 364, 218-220, 1993.

Dyke, L. M., Hughes, A. L. C., Murray, T., Hiemstra, J. F., Andresen, C. S., and Rodes, A.: Evidence for the asynchronous retreat of large outlet glaciers in southeast Greenland at the end of the last glaciation, Quaternary Sci. Rev., 99, 244e259, https://doi.org/10.1016/j.quascirev.2014.06.001, 2014.

Gibb, O. T., Steinhauer, S., Fréchette, B., de Vernal, A., and Hillaire-Marcel, C.: Diachronous evolution of sea surface conditions in the Labrador Sea and Baffin Bay since the last deglaciation, The Holocene, 25, 1882-1897, https://doi.org/10.1177/0959683615591352, 2015.

Golledge, N. R., Mackintosh, A. N., Anderson, B. M., Buckley, K. M., Doughty, A. M, Barrell, D. J. A., Denton, G. H., Vandergoes, M. J., Andersen, B. G., and Schaefer, J. M.: Last Glacial Maximum climate in New Zealand inferred from a modelled Southern Alps icefield, Quaternary Sci. Rev., 46, 20-45, https://doi.org/10.1016/j.quascirev.2012.05.004, 2012.

Greve, R.: Relation of measured basal temperatures and the spatial distribution of the geothermal heat flux for the Greenland ice sheet, Ann. Glaciol., 42, 424-432, 2005.

Greve, R. and Herzfeld, U. C.: Resolution if ice streams and outlet glaciers in large-scale simulations of the Greenland ice sheet, Ann. Glaciol., 55, 209-220, https://doi.org/10.3189/2013AoG63A085, 2013.

Greve, R., Saito, F., and Abe-Ouchi, A.: Initial results of the SeaRISE numerical experiments with the models SICOPOLIS and IcIES for the Greenland Ice Sheet, Ann. Glaciol., 52, 23-30, https://doi.org/10.3189/172756411797252068, 2011.

Hakim, G. J., Emile-Geay, J., Steig, E. J., Noone, D., Anderson, D. M., Tardif, R., Steiger, N. J., and Perkins, W. A.: The Last Millennium Climate Reanalysis Project: Framework and first results, J. Geophys. Res.-Atmos., 121, 6745-6764, https://doi.org/10.1002/2016JD024751, 2016.

Hindmarsh, R. C. A. and Le Meur, E.: Dynamical processes involved in the retreat of marine ice sheets, J. Glaciol., 47, 271282, 2001.

Howat, I. M., Negrete, A., and Smith, B. E.: The Greenland Ice Mapping Project (GIMP) land classification and surface elevation datasets, The Cryosphere, 8, 1509-1518, https://doi.org/10.5194/tc-8-1509-2014, 2014.

Huybrechts, P.: Sea-level changes at the LGM from ice-dynamic reconstructions of the Greenland and Antarctic ice sheets during the glacial cycles, Quaternary Sci. Rev., 21, 203-231, 2002.

Hutter, K.: Theoretical Glaciology: Material Science of Ice and the Mechanics of Glaciers and Ice Sheets, edited by: Reidel, D., Dordrecht, the Netherlands, 1983.

Jennings, A. E., Walton, M. E., Ó Cofaigh, C., Kilfeather, A., Andrews, J. T., Ortiz, J. D., De Vernal, A., and Dowdeswell, J. A.: Paleoenvironments during the younger dryas-early Holocene retreat of the Greenland ice sheet from outer Disko trough, central west Greenland, J. Quaternary Sci., 29, 27-40, 2014.

Kelley, S. E., Briner, J. P., and Zimmerman, S. R.: The influence of ice marginal setting on early Holocene retreat rates in central West Greenland, J. Quaternary Sci., 30, 271-80, https://doi.org/10.1002/jqs.2778, 2015.

Kobashi, T., Menviel, L., Jeltsch-Thömmes, Vinther, B. M., Box, J. E., Muscheler, R. Nakaegawa, T., Pfister, P. L., Döring , M., Leuenberger, M., Wanner, H., and Ohmura, A.: Volcanic influence on centennial to millennial Holocene Greenland temperature change, Sci. Rep., 7, 1441, https://doi.org/10.1038/s41598017-01451-7, 2017.

Larour, E., Seroussi, H., Morlighem, M., and Rignot, E.: Continental scale, high order, high spatial resolution, ice sheet modeling using the Ice Sheet System Model (ISSM), J. Geophys. Res., 117, F01022, https://doi.org/10.1029/2011JF002140, 2012.

Larsen, N. K., Kjær, K. H., Lecavalier, B., Bjørk, A. A., Colding, S., Huybrechts, P., Jakobsen, K. E., Kjeldsen, K. K., Knudsen, K.L., Odgaard, B. V., and Olsen, J.: The response of the southern 
Greenland ice sheet to the Holocene thermal maximum, Geology, 43, 291-294, 2015.

Lecavalier, B. S., Milne, G. A., Simpson, M. J. R., Wake, L., Huybrechts, P., Tarasov, L., Kjeldsen, K. K., Funder, S., Long, A. J., Woodroffe, S., Dyke, A. S., and Larsen, N. K.: A model of Greenland ice sheet deglaciation constrained by observations of relative sea level and ice extent, Quaternary Sci. Rev., 102, 5484, https://doi.org/10.1016/j.quascirev.2014.07.018, 2014.

Lecavalier, B. S., Fisher, D. A., Milne, G. A., Vinther, B. M., Tarasov, L., Huybrechts, P., Lacelle, D., Main, B., Zheng, J., Bourgeois, J., and Dyke, A. S.: High Arctic Holocene temperature record from the Agassiz ice cap and Greenland ice sheet evolution, P. Natl. Acad. Sci. USA, 23, 5952-5957, https://doi.org/10.1073/pnas.1616287114, 2017.

Le Morzadec, K., Tarasov, L., Morlighem, M., and Seroussi, H.: A new sub-grid surface mass balance and flux model for continental-scale ice sheet modelling: testing and last glacial cycle, Geosci. Model Dev., 8, 3199-3213, https://doi.org/10.5194/gmd-8-3199-2015, 2015.

Lesnek, A. and Briner, J.: Response of a land-terminating sector of the western Greenland Ice Sheet to early Holocene climate change: Evidence from ${ }^{10} \mathrm{Be}$ dating in the Søndre Isortoq region, Quaternary Sci. Rev., 180, 145-156, https://doi.org/10.1016/j.quascirev.2017.11.028, 2018.

Morlighem, M., Rignot, E., Seroussi, H., Larour, E., Ben Dhia, H., and Aubry, D.: Spatial patterns of basal drag inferred using control methods from a full-Stokes and simpler models for Pine Island Glacier, West Antarctica, Geophys. Res. Lett., 37, L14502, https://doi.org/10.1029/2010GL043853, 2010.

Morlighem, M., Williams, C. N., Rignot, E., An, L., Arndt, J. E., Bamber, J. L., Catania, G., Chauché, N., Dowdeswell, J. A., Dorschel, B., Fenty, I., Hogan, K., Howat, I., Hubbard, A., Jakobsson, M., Jordan, T. M., Kjeldsen, K. K., Millan, R., Mayer, L., Mouginot, J., Noël, B. P. Y., Ó Cofaigh, C., Palmer, S., Rysgaard, S., Seroussi, H., Siegert, M. J., Slabon, P., Straneo, F., van den Broeke, M. R., Weinrebe, W., Wood, M., and Zinglersen, K. B.: BedMachine v3: Complete bed topography and ocean bathymetry mapping of Greenland from multi-beam echo sounding combined with mass conservation, Geophys. Res. Lett., 44, 11051-11061, https://doi.org/10.1002/2017GL074954, 2017.

Pattyn, F.: A new three-dimensional higher-order thermomechanical ice sheet model: Basic sensitivity, ice stream development, and ice flow across subglacial lakes, J. Geophys. Res., 108, 2382, https://doi.org/10.1029/2002JB002329, 2003.

Rignot, E. and Mouginot, J.: Ice flow in Greenland for the international polar year 2008-2009, Geophys. Res. Lett., 39, L11501, https://doi.org/10.1029/2012GL051634, 2012.

Robinson, A., Calov, R., and Ganopolski, A.: Greenland ice sheet model parameters constrained using simulations of the Eemian Interglacial, Clim. Past, 7, 381-396, https://doi.org/10.5194/cp7-381-2011, 2011.

Seguinot, J., Rogozhina, I., Stroeven, A. P., Margold, M., and Kleman, J.: Numerical simulations of the Cordilleran ice sheet through the last glacial cycle, The Cryosphere, 10, 639-664, https://doi.org/10.5194/tc-10-639-2016, 2016.

Seroussi, H. and Morlighem, M.: Representation of basal melting at the grounding line in ice flow models, The Cryosphere, 12, 3085-3096, https://doi.org/10.5194/tc-12-3085-2018. 2018.
Seroussi, H., Morlighem, M., Rignot, E., Khazendar, A., Larour, E., and Mouginot, J.: Dependence of greenland ice sheet projections on its thermal regime, J. Glaciol., 59, 1024-1034, https://doi.org/10.3189/2013JoG13J054, 2013.

Shapiro, N. M. and Ritzwoller M. H.: Inferring surface heat flux distribution guided by a global seismic model: particular application to Antarctica, Earth Planet. Sc. Lett., 223, 213-224, https://doi.org/10.1016/j.epsl.2004.04.011, 2004.

Simpson, M. J. R., Milne, G. A., Huybrechts, P., and Long, A. J.: Calibrating a glaciological model of the Greenland ice sheet from the Last Glacial Maximum to present-day using field observations of relative sea level and ice extent, Quaternary Sci. Rev., 28, 1631-1657, https://doi.org/10.1016/j.quascirev.2009.03.004, 2009.

Sinclair, G., Carlson, A. E., Mix, A. C., Lecavalier, B. S., Milne, G., Mathias, A., Buizert, C., and Deconto, R.: Diachronous retreat of the Greenland ice sheet during the last deglaciation, Quaternary Sci. Rev., 145, 243-258, https://doi.org/10.1016/j.quascirev.2016.05.040, 2016.

Sole, A., Payne, T., Bamber, J., Nienow, P., and Krabill, W.: Testing hypotheses of the cause of peripheral thinning of the Greenland Ice Sheet: is land-terminating ice thinning at anomalously high rates?, The Cryosphere, 2, 205-218, https://doi.org/10.5194/tc2-205-2008, 2008.

Straneo, F. and Heimbach, P.: North Atlantic warming and the retreat of Greenland's outlet glaciers, Nature, 504, 36-43, 2013.

Tarasov, L. and Peltier, W.: Impact of thermomechanical ice sheet coupling on a model of the $100 \mathrm{kyr}$ ice age cycle, J. Geophys. Res.-Atmos., 104, 9517-9545, 1999.

Tarasov, L. and Richard Peltier, W.: Greenland glacial history and local geodynamic consequences, Geophys. J. Int., 150, 198-229, 2002.

Tabone, I., Blasco, J., Robinson, A., Alvarez-Solas, J., and Montoya, M.: The sensitivity of the Greenland Ice Sheet to glacial-interglacial oceanic forcing, Clim. Past, 14, 455-472, https://doi.org/10.5194/cp-14-455-2018, 2018.

Ten Brink, N. W. and Weidick, A.: Greenland Ice Sheet History Since the Last Glaciation, Quaternary Res., 4, 429-440, 1974.

Van Tatenhove, F. G. M., van der Meer, J. J. M., and Huybrecths, P.: Glacial-Geological/Geomorphological Research in West Greenland Used to Test an Ice-Sheet Model, Quaternary Res., 44, 317327, 1995.

Van Tatenhove, F. G. M., van der Meer, J. J., and Koster, E. A.: Implications for deglaciation chronology from new AMS age determinations in central West Greenland, Quateranry Res., 45, 245253, 1996.

Young, N. E., Briner, J. P., Rood, D. H., Finkel, R. C., Corbett, L. B., and Bierman, P. R.: Age of the Fjord Stade moraines in the Disko Bugt region, western Greenland, and the 9.3 and 8.2 ka cooling events, Quaternary Sci. Rev., 60, 76-90, 2013b.

Vinther, B. M., Buchardt, S. L., Clausen, H. B., Dahl-Jensen, D., Johnsen, S. J., Fisher, D. A., Koerner, R. M., Raynaud, D., Lipenkov, V., Andersen, K. K., Blunier, T., Rasmussen, S. O., Steffensen, J. P., and Svensson, A. M.: Holocene thinning of the Greenland ice sheet, Nature, 461, 385-388, https://doi.org/10.1038/nature08355pmid:19759618, 2009.

Weidick, A.: Observations on some Holocene glacier fluctuations in West Greenland., Meddelelser om Grønl, 165, 1-203, 1968. 
Weidick, A., Kelly, M., and Bennike, O.: Late Quaternary development of the southern sector of the Greenland Ice Sheet, with particular reference to the Qassimiut lobe, Boreas, 33, 284-299, 2004.

Weidick, A., Bennike, O., Citterio, M., and Norgaard-Pedersen, N.: Neoglacial and historical glacier changes around Kangersuneq fjord in southern West Greenland, Geol. Surv. Den. Greenl., 27, 1-68, 2012.

Winsor, K., Carlson, A. E., Klinkhammer, G. P., Stoner, J. S., and Hatfield, R. G.: Evolution of the northeast Labrador Sea during the last interglaciation, Geochem. Geophy. Geosy., 13, 1-17, https://doi.org/10.1029/2012GC004263, 2012.
Young, N. E. and Briner, J. P.: Holocene evolution of the western Greenland Ice Sheet: assessing geophysical ice-sheet models with geological reconstructions of ice-margin change, Quaternary Sci. Rev., 114, 1-17, https://doi.org/10.1016/j.quascirev.2015.01.018, 2015.

Zekollari, H., Lecavalier, B. S., and Huybrechts, P.: Holocene evolution of Hans Tausen Iskappe (Greenland) and implications for the paleoclimatic evolution of the high Arctic, Quaternary Sci. Rev., 182-193, https://doi.org/10.1016/j.quascirev.2017.05.010, 2017. 